\title{
8
}

\section{Pessimism and Modern Thought}

The problem of the worth of life is often regarded among men of the world as one that the healthy have no wish to discuss, and the unhealthy no right to decide. But surely reflective beings must sooner or later be led to consider the worth of conscious life; for self-criticism is an essential part of all mental growth, and cannot rest until it has taken into consideration the whole, as well as the parts, of our activity. But as every new step in critical thought is made by means of a negative criticism of old positions, the question of the worth of life must distinctly appear for the first time in the form of what is inexactly called pessimistic doubt about human life. The doctrine popularly named pessimism, the doctrine that evil is on the whole triumphant, is consequently the immediate subject of the following discussion, whose ultimate aim is the suggestion of some thoughts on the method of estimating the worth of human life. Our plan will be to give, first, a study of certain modern views that bear on our problem; secondly, a critical examination of the bases of these views. We shall preface a very brief account of what is meant by a worth-estimate of human life.

No one familiar with the spirit and objects of modern discussion will find it improper that we should confine ourselves throughout to the study of human life as we know it in this world. Our life this side death is, at all events, the one subject of present moral interest. We are accustomed to bound our desires, even when they

[Reprinted from $F E$, pp. 155-86.] 
extend beyond the limits of our own lives, by the limits of the probable future life of our race. The future means, to the modern man, future generations. Our position is that of Faust, and from that position alone can we clearly reason and definitely hope:

Aus dieser Erde quillen meine Freuden

Und diese Sonne scheinet meinen Leiden.

Kann ich mich erst von ihnen scheiden

Dann mag was will und kann, geschehn.

\section{Worth-Estimates in General}

Pleasure and pain being familiar facts of consciousness, there arises a frequent desire quantitatively to compare different pleasures and pains. Whether this color is as pleasing as that one, this Christmas as merry as the last one, this novel as delightful as another, whether seasickness is more disagreeable than a toothache of equal persistence, whether a broken arm is a greater pain than a wounded conscience, such questions as these are often discussed among men. The only means of deciding them directly is by an appeal to inner personal experience. Discussion, by arousing sympathy, jealousy, or obstinacy, or by appealing to the desire for the approval of others, often alters the natural judgment in such matters. But natural or artificial, the ultimate judgment is based on inner experience. The difficulty, however, in imparting and understanding these elementary worth-judgments lies in the fact that the objects compared are not always clearly defined. It may be regarded as axiomatic that the result of a direct comparison of two present facts of experience is decisive of their relative value as pleasures or pains. If, at the same time, two colors are before me, or if, in immediate succession, I hear two different sounds, or smell two different flowers, my decision as to which is just now the better of the two compared experiences, is a decision beyond appeal. But most of our worth-judgments are not founded on direct comparison of facts of present experience. Two Christmases are separated by at least one year. Toothache and seasickness need not unite at the same time for the torture of the man that compares them. And so through a long list of cases. A worth-judgment is thus often founded on the comparison of a present with a remembered experience, or of two or more remembered experiences with one another. Here the direct judgment is as such indeed above 
appeal. If the experience A appears to me in memory as superior to $B$, then so it appears. But one may still doubt whether $A$ if present would seem preferable to a present experience of $B$. The actually made judgment does not and cannot decide upon this latter point. Of the relative worth as pleasures or pains of $\mathrm{A}$ and $\mathrm{B}$ in themselves we cannot judge, since A and B are experiences (e.g., Christmases, toothaches, sea voyages, novels) separated by a considerable interval of time. Our judgment of their relative worth concerns them merely as they appear in memory.

We have some means of determining the nature of the illusions to which memory is subject, ${ }^{1}$ but these means are insufficient for the purpose of eliminating the disturbing element introduced into our worth-judgments by the lapse of time. Our best effort in this direction is usually made when we have asked ourselves to decide quite deliberately what we should probably do in the way of choice, were the experiences in question now to present themselves for our decision. We substitute deliberate weighing of the remembered for living choice of the present experiences, and our decision is in the end a choice between two conceived actions, i.e., a volition.

Completely hopeless is any attainment of direct judgment when we have to consider the total worth of a long series of experiences, such as are contained in a year or in an epoch of our lives. The sum of any number of successive impressions of pleasure and pain is never given in consciousness. Experience knows of no true summation of experiences. The sum of a series of enjoyments, or of sufferings, is a purely ideal thing, invented by subsequent reflection. You can sum up two heaps of bullets by putting them together and counting them. Facts of consciousness are not bullets to be kept, heaped up and counted. They die as soon as they are born. You might as well seek to sum up the successive tongues of flame in your fireplace as to find the sum of the ever-moving, upspringing, and dying contents of restless human conscious life. What we mean by the sum of a series of pleasurable and painful experiences is commonly simply the total impression of them that remains in memory when we overlook the past. When one says that it was "worth while" to take a certain journey, to read a particular dull book, to learn a certain foreign language; when one

${ }^{1}$ See Mr. James Sully's late book, Illusions: A Psychological Study; in particular ch. $\mathrm{x}$, on "Illusions of Memory." 
poet says that it is better to have loved and lost than never to have loved at all, or when another poet tells each of us to count over the joys of his life, and then to "know, whatever thou hast been, 'tis something better not to be"; in all such cases we have to do with no real summation, but with an estimate based on the qualitative difference between the present total impressions of two represented sets of experiences. Not even such a rough summation is there here as is made in case of a hasty estimate of the size or weight of a present material mass. For the parts of the material mass coexist, and the total impression is made without any considerable lapse of time during the survey of the parts. But the worth-estimate is concerned with non-coexistent objects, separated by large periods of time. The one estimate is capable of verification; the other is beyond verification. The estimate of the actual size of a material object is the goal of inquiry. The most careful estimate of the mathematical sum of a long series of pleasures and pains would really be of no importance whatever if it chanced to disagree with a worth-estimate based upon a mere feeling or total impression of the acceptability or non-acceptability of the series of impressions as a whole. Prove to me that during a certain mountain walk I had in sum more pain than pleasure, and you will not prove to me that my walk was a failure. I may still have the total impression of the acceptability of the whole experience, an impression resulting from the fact that I have nearly forgotten the vexations of the walk, and have retained a vivid memory of the views and of the mountain air. This total impression you shall in vain seek to overcome with your estimate. I should not care for your sum if you were to make it with the exactitude of a recording angel. My mere feeling of the worth of mountain-climbing decides the whole matter.

Thus, then, our estimate of the worth of any large fragment of human life is founded, not so much on an estimate of the mathematical sum of its separate experiences, as on a total impression of the worth or significance of the entire series, when viewed from some other moment of time. The knowledge that this total impression is the basis of all judgment of life, is at the bottom of the bec olim meminisse juvabit of the man in present misfortune. Hope says that even if our unhappy experiences exceed in number and intensity our happy experiences, still the future will arbitrarily turn the scale by regarding the whole series of experiences as essentially 
good. And so no man, unprejudiced by a system, tries to apply a strictly utilitarian test to the judgment of the worth of his own experience. The utilitarian test would require a strict summation and balancing of pleasures and pains. Such summation is in fact never possible. If it were possible, the balance sheet of joy and misery would be for most men of no use whatever. ${ }^{2}$

Worth-judgments concerning human life, as a whole, are, therefore, not reducible to assertions about the mathematical sum of pleasures and pains. What, then, determines these judgments? Our historical study is intended to answer in part this very question. So much is, however, clear: that a worth-judgment about human life is the result of an act of mind, somewhat resembling an ordinary practical volition. This life is good, this life is evil, these opposing judgments are two opposing attitudes of will. The ultimate decision in the matter is not to result from a mathematical estimate, but from moral insight. The nature of this insight does not yet appear. But we must be clear as to what we are seeking, viz., not a balance sheet of evil and good, but a watch word to determine our principles of action; an everlasting yea or nay, that shall relate to the whole of life.

\section{Pessimism and Modern Poetry}

Ethical "criticism of life," to borrow Mr. Matthew Arnold's phrase, takes in this century many forms. Chief among them are poetry and speculative philosophy. The poetry of the nineteenth century has been largely the result of the movement in mental life for which is chiefly responsible the revolution, political and social,

2 This problem of the "Hedonistic calculus," is discussed by Mr. Sidgwick, Methods of Ethics, Ist ed., bk. II, ch. iii, sec. 2, p. I20, sqq. The fundamental importance of the whole question seems to be hardly appreciated by most utilitarians. To tell us to seek for the "greatest possible sum of happiness," when the balance of pleasures and pains can neither be made, nor, if made, accepted by most unprejudiced men, as expressing their sense of the worth of their own experience: this is simply to tell us to behead the Cheshire cat that has no body. The connection of the subject with the present question appears very well in v. Hartmann's essay, "Ist der Pessimismus wissenschaftlich zu begründen?" (Philosoph. Monatsh., bd. XV, hft. X, p. 589 , sqq.), where the author coolly assumes (p. 591), "that objection to this Hedonistic estimate of the worth of life ... does not affect the truth of pessimism, which has for the first to do only with the proof of the fact that the balance of pleasure in the world gives a negative result." In other words, "Off with the cat's head," whether or not it has any body. 
at the close of the eighteenth century. The revolution meant for the poets the suggestion of a splendid or terrible future for the human race, and the present realization of a fullness of emotional life unknown to the earlier decades of the century. Here was material enough for magnificent dreams and for stirring life-pictures. The schools of poetry that expressed the spirit of the age were, however, weighted with something that proved fatal to very many promising talents; and this something was the tendency to reflection. To have an emotion is one thing, to sing it a very different thing; but to sing it even while you are speculating about its philosophic significance is the saddest of all the tasks imposed by the envious gods. Yet such is the task to which are condemned more than half of our best modern poets. They can not have the pure emotion; or, if they can have it, they can not sing it purely and simply. The demon of reflection is continually whispering in the singer's ear: What is all this good for? Whence comes it? What has it to do with the inmost nature of things? What bearing has it on the conduct of life? The singer, unless he is a chosen one of all, stammers and blunders; or, recovering himself, takes refuge in grand metrical digressions of a semi-metaphysical nature. In fact, because the revolution itself expressed tendencies largely speculative, and because thought-problems were never before so widely known or discussed as they are in this century, the poet in mirroring his own age is forced to seek such union of thought with emotion as was never before demanded of the verse maker.

Emotion tinged with speculative reflection results in the writing of what is called romantic poetry. High or low, grand or inane, nearly all sincere modern poetic effort is in this sense romantic. A sort of secondary, artificial freedom from reflection we find in a few classic modern poems; a few natural songs from time to time spring up unaffected by the reflective spirit. But on the whole, for good or for evil, romanticism is triumphant: for good, when the thought and the emotion unite to form a perfect whole, a colored but still unblurred crystal, a Prometheus Unbound or a first part of Faust; for evil, whenever the thought mars the purity of the feeling, the feeling the definiteness of the thought. ${ }^{3}$

Of all the subjects of reflection in the romantic poetry, none is more familiar than the question of the meaning and worth of

${ }^{3}$ The rest of Sec. II was incorporated in ch. v of The Religious Aspect of Pbilosophy.-Ed. [J. L.] 
human life as a whole. The first and natural answer of the modern poet to this question is well known. Human life means for him the emotional side of life. The highest good, when found, must be an emotional good. The romantic poet, criticizing life, must aim to make clear what kind of emotional condition is the most satisfactory one. Notice that in this view we have no mere truism. Many forms of Hedonism would oppose the doctrine that in the intenser emotions can be found the ideal states of consciousness. The common sense of men of the world sees in the more moderate pleasures of polite leisure, in the attainment of practical knowledge, in a successful professional or business career, the sources of permanent satisfaction. Several schools of ancient philosophy regarded tranquillity as constituting the essence of a blessed life. But to all this the spirit of modern poetry was from the outset violently opposed. Tranquillity, once exchanged for storm and stress, is not again regarded as the goal. Active emotion, intense in quality, unlimited in quantity, is what the poets of the revolution desire. One need only mention Werther, The Robbers, The Revolt of Islam, Manfred, Faust, to suggest what is meant by this spirit of the revolutionary poetry.

Life, then, can be of worth only in so far as it is full of the desirable forms of poetic emotion. But is such fullness of life possible? Is the view that makes it the ideal a tenable view? Must not the consistent following of this view lead ultimately to pessimism? The answer to this problem is the history of the whole romantic movement. Here must suffice a sketch of some of the principal results of the movement.

The stir of modern life, then, has awakened sensibility, quickened desire, aroused the passion for freedom, disturbed old traditions. Above all, the theological ideals of life have been for the romantic poet disturbed, perhaps shattered. His highest good must be sought in his own soul. What is the consequence? First, of course, a sense of splendid independence, a lofty spiritual pride. The joy of freed emotion is equaled by few delights on earth. The self-worship of poetic genius is surpassed by few forms of conceit. Shelley, rejoicing in his strength, writing The Necessity of Athe$i s m$, and defending, in all innocence of evil, adultery and incest, is a good example of the expression of this spirit. Lavatar's account of the nature of genius is another instance: "As the apparitions of angels do not come but are present, do not go away but are gone, 
as they strike the innermost marrow, influence by their immortality the immortal in men, vanish and yet still influence, leave behind them sweet shuddering and tears of terror, and on the countenance pale joy, so the operation of genius. Describe genius as you will-name its fruitfulness of soul, faith, hope, love-the unlearned, the unlearnable-the inimitable, the divine-that is genius. 'Tis inspiration, revelation, that may be felt, but not willed or desired; 'tis art above art, its way is the way of the lightning."4 I cannot quote a tenth part of this rhapsody, wherein the selfadmiration and the mutual admiration of the young men about Goethe, in the years just before and after 1780 , receive a characteristic expression.

This pride leads directly to the effort to build up a wholly new set of ideals. The patience of the statesman, of the student of science, of the business man, is unknown to these forceful young men. They must make a world of their own, and in a day, too. At the same time they are without any definite faith. In fact, definite faith would endanger for them the freshness of their emotions. They fear any creed but one self-made. And they can more easily tear down than build up. One of the most interesting of the young geniuses of that age ${ }^{5}$ is the early lost Novalis (Friedrich v. Hardenberg), a representative, like Shelley after him, of the emotional or romantic poetry in its pristine innocence. A truly noble soul, joined to a weak body, oppressed by many troubles, unable to grow to full manly spiritual stature, he shows us the beauty and imperfection of the emotional movement in close union. He writes pages of vague philosophy, which afterwards impressed the young Carlyle as an expression of a sense of the deep mystery of life. You find delight in wandering through the flowery labyrinths of such speculation; but you come nowhere. Only this is clear: the young poet persists that the world must in some way conform to the emotional needs of man. And he persists, too, that a harmonious scheme of life can be formed on a purely romantic plan, and only on such a plan. He actually explains no reality and completes no scheme of life. He hints, at length, that the Catholic church is the

4 See the passage at much greater length in Koberstein's Gesch. d. deutch. Nationalität, bd. IV, p. 26 of the $5^{\text {th }}$ ed.

5 The age in question extends from 1770 to 1830 . No special effort is here made to follow chronological order. Our purpose is to cite illustrations, not to give a history. 
best expression of the needs of man. With this unsatisfactory suggestion, the little career of wandering ends in death. But in what could it have ended, had life continued?

Perhaps in what was called by the close friend of Novalis, Friedrich Schlegel, the romantic irony. This is the next stage in the growth, or, if you like, in the decay of the romantic spirit. Emotion is our guide and our goal. But what is emotion? Something changeable and by nature inconsistent. Each emotion sets up a claim to fill the whole of life. For each new one, the earnest poetic soul feels willing to die. Yet each is driven away by its follower. The feet of them that shall bear it out are before the door even while the triumphant emotion is reigning over the heart within. Fullness of such life means fickleness. Novalis, upon the death of his betrothed, made a sort of divinity of the departed, and dated a new era from the day of her death. His Diary was for a while full of spiritual exercises, suggested by his affliction. He resolved to follow her to the grave in one year. Within this year he was betrothed anew. If such is Novalis, what will be a lesser spirit? Conscious of this inevitable decay of each emotion, Friedrich Schlegel suggests that one should make a virtue of necessity and declare that the higher life consists in a sort of enthusiastic fickleness. The genius must wander like a humming bird in the garden of divine emotions. And he must be conscious and proud of his wanderings. Activity, or rather agility, is his highest perfection. The more numerous his emotions, the nobler the man. The fickler the man, the more numerous his emotions. This conscious union of nobility and fickleness is the romantic irony, which consists in receiving each new enthusiasm with a merry pride. 'Twas not the first, and will not be the last. We see through it, even while we submit to it. We are more than it, and will survive it. Long live King Experience, who showers upon us new feelings!

So much for an ingenious and thoroughly detestable view of life, in which there is for an earnest man no rest. This irony, what is it but the laughter of demons over the miserable weakness of human character? The emotion was to be our god. It turns out to be a wretched fetich, and we know it as such. 'Twas mine, 'tis his, and has been slave to thousands. It is gone, though we trusted in it. It was our stay, and it has flowed away like water. This is not fullness, but hollowness, of life. And how shall the romantic irony supply the vacancy? This irony is but the word of Mephistopheles 
about the ruin of Gretchen: Sie ist die erste nicht. Not the first change of emotion is this present one; not the first breaking up of the fountains of the great deep within us; but what misery in that thought! Then there is nothing sure, nothing significant. In our own hearts were we to find life, and there is no true life there; only masks with nothing beneath them; only endless and meaningless change.

The consciousness of this result is the next step in the selfcriticism of the romantic spirit. The consequence is what Hegel in the Pbänomenologie des Geistes, described under the name of Das Unglückliche Bewusstsein, and what is more familiarly known to us as the Byronic frame of mind. The very strength of the previous emotion renders this consciousness of the hollowness of emotion the more insupportable:

When the lamp is broken

The light in the dust lies dead.

The brighter the lamp, the deeper the darkness that follows its breaking.

The romantic despair thus described took many forms in the poetry of the early part of the century. To describe them all were to go far beyond our limits. A few forms suggest themselves. If we are condemned to fleeting emotions, we are still not deprived of the hope that some day we may by chance find an abiding emotion. Thus, then, we find many poets living in a wholly problematic state of mind, expecting the god stronger than they who, coming, shall rule over them. Such a man is the dramatist and writer of tales, Heinrich von Kleist. "It can be," writes this poet to a friend, December, $1806,{ }^{6}$ "it can be no evil spirit that rules the world, only a spirit not understood." In such a tone of restless search for the ideal of action, Kleist remains throughout his life. No poet of the romantic school had a keener love of life problems purely as problems. Each of his works is the statement of a question. Kleist answered his own questions at last by suicide. Others have other ways of fleeing misery. Ludwig Tieck, after running through the whole round of romantic questions, rids himself of his demons by turning his attention to other literary work, and lets most of the old romantic ideals alone. Friedrich Schlegel finally escapes from himself by means of scholarly toil and Cath-

${ }^{6}$ I quote from J. Schmidt, Gesch. d. deutchen Literatur, bd. II, p. 472. 
olic faith. Hölderlin takes refuge in a mad-house. Shelley manages to endure, while he lives, by dint of childlike submissiveness to his emotions, joined with earnest hope for yet better things. Schiller joins with Goethe in a search for perfection in the ancient Greek world. There are many fashions of quieting the restlessness that belonged to the time, yet what one of them really answers the problems of the romantic spirit? There is still the great question: How may mankind live the harmonious emotional life, when men are driven for their ideals back upon themselves, when traditional faith is removed, when the age is full of wretchedness and of blind striving, when the very strength of poetic emotion implies that it is transient and changeable? The conscious failure to answer this question is more or less decided pessimism.

Could modern poetry free itself from that reflective tendency in which we have found its most prominent characteristic, the pessimism could disappear with the criticism of life. But this is impossible. Omit part of our lyric poetry, some of our comedy and of our satire, and the rest of our best nineteenth-century poetic work is a more or less conscious struggle with pessimism. The grounds and the nature of this struggle have been set forth in the foregoing. The poet once for all accepts the emotional criterion of the worth of life. Determining to see in the harmonious emotional life the best life, feeling as the most certain of principles that "there is a lower and a higher," the poet seeks to picture the perfect existence thus defined. Failure means for him pessimism; not v. Hartmann's really quite harmless "eudämonologischer Pessimismus," but the true pessimism of the broken will, that has tried all and failed. The life that ought to be, cannot be; the life that is, is hollow and futile; such will be the result of disappointed idealism. In our time, the idealistic poets that are not pessimists have all, nevertheless, fought more or less consciously the same battle with pessimism. Think only of the Excursion, or of the In Memorium, or again of Faust, that epitome of the thought of our century.

But before we allow ourselves a word on the relation of Faust to our problem, let us look a little closer at Byron. Faust is the crown of modern poetic effort. If that fails as a solution, all in this field has thus far been lost. But in Byron there is a confessed, one might even say a professed, moral imperfection, whose nature throws light, not so much on the solution of the problem of pessimism, as on the problem itself. 
The development of Byron's poetry has two very marked periods, the sentimental and the critical. The sentimental Byron of the years before 1816 is not of very great historical interest. The Byron of Manfred, Cain, and Don Juan, represents an independent phase of the romantic movement, whose faults are as instructive as its beauties. This period of Byron's poetry is of course but very roughly described by the word critical, yet that word is at any rate suggestive. A sensitive man, and yet heroic, strong in spirit, but without fixed ideals of life, a rebel by nature who yet finds no greater soul to lead him, no faithful band to follow him in any definite effort for mankind, Byron is a modern likeness of him that in the legend afterwards became St. Christopher. Only Byron seeks the strongest without finding him, learns to despise the devil, and never meets the devil's master. Worn out with the search, the poet flings himself down in the woods of doubt and dreams Don Juan. We look in vain for the right adjective with which to qualify this poem: it is so full of strength, so lavish of splendid resources, and yet in sum so disappointing. It has no true ending, and never could have had one. It is a mountain stream, plunging down dreadful chasms, singing through grand forests, and losing itself in a lifeless gray alkali desert. Here is romantic self-criticism pushed to its farthest consequences. Here is the self-confession of an heroic soul that has made too high demands on life, and that has found in its own experience and in the world nothing worthy of true heroism. We feel the magnitude of the blunder, we despise (with the author, as must be noticed, not in opposition to him) the miserable petty round of detestable experiences-intrigues, amours, dinners-in brief, the vulgarity to which human life is reduced; but the tragedy is everywhere to be read between the lines, not in what is said. The romantic spirit has sought in vain for the satisfactory emotional state, and for the worthy deed to perform, and now rests, scornful and yet terrified, in dizzy contemplation of the confused and meaningless maze of sensations into which the world has resolved itself. "There is nothing there to fear or hope," this spirit seems to say.

When Bishop Berkeley said there was no matter, And proved it, 'twas no matter what he said.

Or again: 
To be or not to be? Ere I decide

I should be glad to know that which is being;

'Tis true we speculate both far and wide, And deem, because we see, we are all-seeing.

For my part, I'll enlist on neither side,

Until I see both sides for once agreeing.

For me, I sometimes think that life is death,

Rather than life a mere affair of breath.

In Manfred the same spirit seeks another, and not quite so successful a form of expression. The only peace that can come to this world-weary spirit, Manfred expresses at the sight of a quiet sunset. The only freedom from eternal self-examination is found in an occasional glance at peaceful nature.

\section{It will not last,}

But it is well to have known it though but once;

It hath enlarged my thoughts with a new sense,

And I within my tablets would note down

That there is such a feeling.

The famous last words of Manfred,

Old man, 'tis not so difficult to die.

coming as they do after all Manfred's vacillation upon just this point, indicate the final resolution of despair to brave all possible wretchedness from without for the sake of feeling within, in all its strength, though but for a moment, the fierce defiance of the rebellious Titan. Hungary for deeds, finding nothing to do, fearing the possible future life, and hating the present, the hero at last resorts to an untrue but stirring assertion of absolute personal independence of all the hateful universe here and hereafter:

Thou didst not tempt me, and thou couldst not tempt me.

I have not been thy dupe, nor thy prey-

But was my own destroyer, and will be

My own hereafter.

This is pessimism that overleaps itself and falls on the other. The outcome of self-analyzing romanticism is the determination to build afresh a world that shall be nobler than this poor world 
of decaying passive emotions. Feeling will not do. Manfred attains something by action, even though he first acts in the moment of death. Doing work of some kind is, then, that to which we are necessarily driven. But if the action of defiance can make death tolerable, why might not some kind of activity make life tolerable? Is not the worthy life then to be found, not in emotion, but in work? Is not the ideal state the ideal activity, not the ideal feeling? This suggestion is at the foundation of the prototype of Manfred, the Faust of Goethe.

Praise of the first part of Goethe's Faust is nowadays superfluous. Doubtless the work is a torso, ${ }^{7}$ but so is the life of man. Extravagant encomium of Faust, such as that wherewith Hermann Grimm has marred, as with a showman's harangue, the conclusion of his otherwise most instructive Lectures on Goethe, seems as out of place as applause in a cathedral. The poem is grand and profound, because the life problems it so truthfully portrays are grand and profound; in form, if you except digressions, it is sublimely simple and unassuming. Its imperfections are as open to view as is its grandeur. The doctrine of the poem may be thus briefly suggested. Here is a world wherein nature, the expression of divine intelligence, is perfect, wherein man, by the same divine wisdom, is left in darkness and confusion. The angels, who simply contemplate nature's perfection, are the "true sons of God." But they do nothing. They only see and think. Man is to act. By his action he is freely to create such perfection as already passively exists in nature. That is, his life is to become an harmonious whole. The postulate of the Lord is that this is possible. Mephistopheles holds the opposite opinion. The question is to be solved by the case of Faust.

Faust is a man in whom are combined all the strength and weakness of the romantic spirit. No excellence he deems of worth so long as any excellence is beyond his grasp. Therefore his despair at the sight of the great world of life. So small a part of it is his. He knows that he can never grow great enough to grasp the whole, or any finite part of the whole. Yet there remains the hopeless desire for this wholeness. Nothing but the infinite can be satisfying. Hence the despair of the early scenes of the first part. Like Byron's Manfred, Faust seeks death; but Faust is kept from

${ }^{7}$ Cf. the opinion of M. Edm. Scherer as quoted in Mr. Matthew Arnold's essay, "A French Critic on Goethe," in the Mixed Essays, p. $29 \mathrm{I}$. 
it by no fear of worse things beyond, only by an accidental reawakening of old childish emotions. He feels that he has no business with life, and is wholly a creature of accident. He is clearly conscious only of a longing for a full experience. But this experience he conceives as mainly a passive one. He does not wish as yet to do anything, only to get everything. ${ }^{8}$ But at the same time with this desire for a tempest of new feelings, Faust has the consciousness that there never can be a satisfactory feeling. Mephistopheles, stating the case of the contented man of the world, assures him that the time will come for enjoying good things in peace. Faust indignantly replies that pleasure can never deceive him, the tolerable moment never come. In making this very assertion, however, and in concluding his pact with Mephistopheles upon the basis of this assertion, Faust rises above his first position, and assumes a new one. The satisfactory pleasure can never be given to him, and why? Because he will always remain active. Satisfaction would mean repose, repose would mean death. Life is activity. The meaning of the pact is of course that, for good or for evil, all the existence of a man is work, and that no one is ever wholly lost so long as the power of accomplishment remains his. But if work is the essence of life, then satisfaction must be found not in feelings but in deeds. The world is good if we can make it so, not otherwise. The problem of Faust is, therefore, the discovery of the perfect kind of activity.

With this insight the romantic spirit has risen beyond itself. The essence of romanticism is the desire for fullness of personal experience. The essence of this new spirit is the eagerness to accomplish something. The difference is vast. Faust, following this new tendency, might be led to an obscure toiling life of endless selfsacrifice. His pessimism (for in the early scenes he is a pessimist) might give way before unquestioning heroic devotion to some great end. Does this take place? We know too well the answer. The whole poem is indeed a conflict between the two tendencies of Faust, but the first, the desire for manifold passive experiences, is until the last scenes of the second part predominant. Faust is active, but his activity is mainly a continual pursuit of new experiences. Even at the end he is not active as other men are active; his

${ }^{8}$ Cf. the lengthy discussion of this point in Friedrich Vischer, Goetbe's Faust, Neue Beiträge zur Kritik des Gedicbts, especially p. 291, and p. 304. "Er (Faust) weiss also für jetzt nur von der Lust." 
work is done by magic; and the accomplishment for whose sake he is at last willing to say, This is the bighest moment, is an anticipation, not a reality. In the real world the satisfactory work is never found. And thus the solution of the problem is not fully given, though the poet, while suggesting it, has done more than any other modern poet. The revolution had furnished as life-ideals grand emotion and heroic action. The two cannot wholly be harmonized. The highest forms of activity imply self-sacrifice, drudgery, routine, cool-headed calculation, realism. The highest forms of emotion, pursued by themselves, intoxicate and enervate. It is the purpose of Goethe to lead his hero through the various stages of emotional life for the sake of making him prefer in the end a mode of action to all forms of simple emotion. The result is to be a man above the deadness of ordinary work-a-day realism, yet as devoted to toil as the stupidest realist. There is to be a free surrender of a full self to the service of some high end. Nothing is lacking to the conquest over pessimism, except the clear statement of that for which the converted Faust is to work. The goal of activity once found, the problem will be solved, and the devil's wager lost. But the dim allegorical suggestions of the second part will not suffice to give us the account of what is wanted. Faust is to work for human progress, and progress means the existence of a whole nation of hard-laboring, fearless men who fight forever for their freedom. To have been the father of such a people is the highest blessedness. Good, indeed, we say; but to have wrought by the devil's aid, through magic and oppression, is this the highest? Is this the type of the best activity? And is the great problem after all really solved? For what is the ultimate good of the eternal warfare with nature in which mankind are thus left? Faust leaves behind him a nation of toilers, whose business it will be to build dikes to keep the sea out. A worthy end of romantic hopes, truly! That Goethe himself is not wholly content therewith, is proven by the epilogue in heaven, which means, if it means anything, that the highest end of human activity is something very fine, but altogether inexpressible, invisible, inconceivable, indefinite, a thing of ether and fog. One longs in this last scene for the presence of Mephistopheles, who surely has as much right there as in the prologue, and who would be sure to say, in his terse and sinewy fashion, just the right and the last word about the whole business.

The incompleteness of Faust is the incompleteness of modern 
thought. The poet is silent about the final problem, because modern thought is still toiling away on the definition of the highest human activity. And so we naturally turn from our hasty survey of the poetic movement of the revolutionary period to a sketch of certain forms of speculative thought regarding this problem of pessimism.

\section{Pessimism and Speculation}

At the outset of our discussion, we rejected the view that estimates the value of life as an accountant estimates a man's assets, viz., by summation and balancing. The only useful speculations on the worth of life are those that regard life with reference to some accepted goal; itself a state of consciousness in some animate being. Given the goal, we can compare therewith the work actually done in human life, and see how nearly the desired state has been approached. The desired state may imply a series of experiences, in which, upon summation, there is found to be an excess of pain over pleasure. Yet this state may be demanded as the highest state, and the implied series of experiences may be accepted as a means thereto, without any question on the part of the acceptor as to the balance of pleasure and pain. The worth of life is judged solely with reference to the goal.

What determines the choice of our goal need not here be considered at length. It is enough to note the following principles: ( $\mathrm{I}$ ) If we choose any end as the end to be sought, our work towards that end is accompanied by an unrest, i.e., by a constant disposition to alter the content of our consciousness, so long as we are at work. The attainment of the goal means the cessation of the unrest. To seek the goal and to seek to quiet the unrest are, therefore, one and the same thing. (2) Unrest has no absolute worth. For otherwise, unrest itself would be our goal. But unrest is not the goal; it is the consciousness that we are seeking our goal. The goal has worth in itself; but the unrest has worth only as bringing us near the goal. (3) If we have fixed upon any goal, so that we judge life as good in so far as it approaches, bad in so far as it does not approach, the goal, then our estimate of the worth of life is by implication fixed, and can be altered only by an alteration of the goal. But the choice of the goal is an act of volition. We cannot prove to another person that so and so is the goal. We can tell him what our goal is, and can hope that we shall find or awaken in him a sympathy with our en- 
thusiasm. The choice of an object in life defies logical demonstration. Men catch from other men moral ideals, or now and again originate new ones for themselves. Never do they receive their moral principles as they do their mathematics, by rigid demonstration. The ultimate axioms of conduct are practical volitions; while the ultimate axioms of science, if volitional in nature, are yet volitions of another order. (4) But, in accepting several goals at once, or in altering a previously accepted goal, we are, to a certain extent, influenced by a logical consideration, viz., consistency. If two accepted goals of action are found to conflict, we seek to harmonize them by compromise, or by the elimination of one of them. If one goal is found, upon analysis, to imply a self-contradiction, we alter it. If, upon better understanding of what an accepted goal implies, we alter our position towards it, our reflection has influenced our volition. Thus, there arises a sort of moral dialectic, and the independence of our will, in accepting a particular object as the goal of our striving, is limited by the reaction of our thought upon each new ideal that we set up.

These principles being admitted, the discussion of the worth of life reduces to the following questions: (I) Are the goals of ordinary human action such as can be clearly defined at all? (2) If defined, will they be found to be consistent, or inconsistent and mutually destructive? (3) If this is the case, can any process of dialectic purification reduce them to unity, and set up a consistent and universal ideal of life? (4) If this last ideal is found, is it to be regarded as attainable?

The first question is generally answered with a qualified, sometimes with an unqualified, affirmative. That at least some of the popular objects of human life are definable, is implied in nearly every discussion of the subject, whatever the result of such discussion. In so far as such goals of action are not definable, the life that seeks them has, from our point of view, no definable worth.

Given an affirmative answer to the first question, the second presents itself in two forms. It may relate to the objects of the life of some one individual, as given to and for him. Or it may relate to the various ideals of various people, considered in their social relations. In both its forms we must answer the question in the same way. The various ordinarily accepted aims of human life, both in individuals for themselves and in society at large, do conflict. Vacillation, inner struggles of all kinds, show us how disunited are our 
own individual ideals of life; aggression and cruelty, even discussion, even the forms of compact and alliance, show how great the conflict, or the danger of conflict, between various human aims. But if life as a whole is to have worth, these conflicts, it would seem, must, on the whole, be brought to an end. For they mean hindrance and extra unrest even to the victors; total failure, endless unrest, to the vanquished.

The third and fourth questions are the places of the greatest controversy. If one may be permitted to affirm anything about people's answers to questions that they themselves did not in so many words formulate, one may with fair certainty say that on his negative answer to our third question depends, in part, Schopenhauer's peculiar form of pessimism, while on the affirmative answer thereto depends the optimism of the most of the Hegelian school, as well as the optimism of the evolution philosophers. For the Hegelian, all conflicting human ends finally, through a dialetic process, harmonize in one highest end, the self-consciousness of the Absolute Spirit. For the believer in physical evolution, all human ends will at length harmonize in the one end of giving self, through the perfect satisfaction of our fellows, the greatest satisfaction possible. Such at least is the sense of a late formula propounded by a thoroughly competent authority. But for Schopenhauer such harmony is impossible. The greater our knowledge, the better shall we see, according to Schopenhauer, that warfare is of the essence of the will, and that the various objects of the will, not only are incompatible, but must forever remain irreconcilable.

But if the third question were answered in the affirmative, if the one goal were fixed upon, the fourth question would remain. This fourth question, viewed apart from the third, is answered negatively by Schopenhauer, affirmatively by the evolution philosophers, presumably with a weder noch by most of the Hegelians. Let us look for a moment at the matter. Given any goal, then life is of worth in so far as it approaches that goal. Endless unrest would be failure. But now, says Schopenhauer, life is will, and will is unrest. Given any goal as the highest, then attainment would mean absolute rest. Absolute rest would mean cessation of will, and so death. But if attainment of the absolute end means death, then in life the end cannot be attained. Life can, therefore, never have absolute worth. Whatever is a goal with nothing beyond cannot be life, but must be death. Whatever life has no final goal within its 
reach, must be an eternal failure. On such a basis is Schopenhauer's pessimism built up.

Let us consider the subject in another way, making ourselves more independent of Schopenhauer's metaphysic, and taking a course that leads to a direct attack upon that stronghold of modern optimism, viz., upon the ethical significance of the doctrine of progress. Some people at one time liked the phrase "perfectibility of man," instead of the modern phrase "evolution of humanity." But when men looked to history for proof of this "perfectibility," one trouble in their way was the sad fact that the perfectible creature has never yet been perfected. If not quite "so wunderlich als wie am ersten Tag," he is still not a little defective; in fact, mostly a blunderer, and often a knave. "The progress of man" seems, then, a more satisfactory term wherewith to sum up the facts of history. But too many optimistic congratulations must not yet be exchanged over this fact of progress. It is a fact; progress is for the better, and worship of savage innocence was a mere sentimental whim of the strait-laced eighteenth century. But what follows thence about the nature of life? Alas! too little. This worship of progress is only another bit of sentiment, useful in its place, but of not very tough moral fiber. Stout-hearted men in this great, dark universe, must be ready to take their own view of the worth of life, quite apart from their knowledge of a link or two of the myriadcoiled chain of the world history. For reflect: this bit of life that we here know, is but a fragment (a cross-section as it were, with a little piece added lengthwise) out of an eternity of events. Here is an endless sequence of causes and effects. Now, on any hypothesis as to the powers that direct the universe, so much is certain. After an infinity of time (of progress or of retrogression, or of endless circular motion? Who shall say?), the world spirit of the world force has brought forth this present world of human life, with all its vast imperfections. The world plan or no-plan (we need not here discuss which) involves as a possible result, after the lapse of infinite ages of change, all the failure and worthlessness and blind struggling that is here about us in these oppressed millions of wasted lives, in these thieves and cut-throats, in these filthy, in these halt and blind, in these stupid wretches that make up the lower classes of society, in these heart-sick, lonesome wanderers that seek the outskirts of civilization, in all these fellow-beings to whom our hearts go out in pity even while we despise their weak- 
ness. This is one result of the infinite ages. Take the worst wretch ever heard of-a Guiteau or a Judas. It took just an eternity to produce him. Now, this being so, it is enough. What the world plan is we need not judge. What it may imply, we by this example see. It may imply always just, as it now realizes, the existence of what we in this discussion are regarding as evil, namely, hopeless striving ending in failure, fierce conflict ending in mutual destruction of the fighters. Here helps no progress. This world may get better for a while; what are a few million years in an eternity? But there is no evidence to show that progress is eternal and regular. If progress had gone on from eternity, where would be room for imperfection now? Much as many efforts in theodicy become inconsistent with orthodox theology in that they necessarily imply that the evil of this world, being an essential of finite and rational existence, must continue into the next world and enter heaven itself, even so this optimism of progress proves too much. If evil is possible and actual after infinite ages of progress, then a further infinity of progress might never remove the evil. And why, then, is progress a very cheering fact? But if the infinite past has not been all progress, then what hope for the future? The most probable view of the universe as a whole would seem then to be the view, according to which growth and decay go on forever in cyclic rhythm. At any time in the past or future we should expect to find much such a universe of striving and imperfection as we now find, the forms infinitely various, the significance wearily the same.

So much for the skeptical consideration of our fourth question. To return now for a few final words about our third question. In the present writer's mind there is no doubt that the third question can be answered affirmatively; that there is an ultimate goal, to which, by simple self-knowledge, by immanent criticism of human desire, all the various and conflicting goals of action can be reduced. Whether all men will ever come to recognize this one goal, whether by any process of dialectic purification the many will for all men be stripped of their deceits and seen in their reality as but one, we do not know. That makes little difference for the purposes of our third question. Nor can we go far now into the defense of this as our goal. We must content ourselves with a mere statement. The one goal is the rendering as full and as definite as possible all the conscious life that at any moment comes within the circle of our influence. Devotion, then, to universal conscious life, is the goal 
of conscious life itself; or the goal is the self-reference or self-surrender of each conscious moment to the great whole of life, in so far as that whole is within reach. Separation from other conscious life means failure. Conscious union with other conscious life means for every conscious being success in proportion to the fullness, clearness, and definiteness of that union. This union is the highest goal, not for itself logically demonstrable as such, but deducible from the other actual goals of mankind when they are analyzed in their true meaning.

This being the goal of action, the fourth question recurs. Is the goal attainable? The trust in progress is, as we just saw, no secure support. Progress seems to be a fact of very limited scope, magnified rather unduly in our eyes by a certain praiseworthy enthusiasm of contemporary thought. No hope then there. Critical thinkers can not be permanently caught with such chaff. Optimists or pessimists we must be here and now, in and for this present earthly life in this nineteenth century. Everybody then must finally settle the question with his own soul. Discussions like the present but try to state the problem, that each may have its terms before him. And what is the problem as our discussion has defined it? Here is our final statement:

If the goal is conscious union of every conscious being with the great whole of conscious life, and if rest is impossible until that end is attained, and possible if that is attained, can we hope under human conditions to attain this goal? The answer is: in perfect union and harmony with the whole of conscious life we can at moments feel ourselves. Self-sacrifice chief of all, and in the next rank hard work for any impersonal end, or the mere contemplation of active life, the union with others for the doing of work that involves no warring with an opposite party, even warfare when carried on for the good of the whole of conscious life; whatever, in a word, impresses on each his own insignificance and still more the grandeur of the great ocean of conscious activity below, about, and above him: all such deeds and experiences serve to accomplish what is meant by union of each being with the whole of life. Yet such union is perfected only in moments. For the rest of the time selfishness, self-conceit, struggle with hated equals, in a word, unrest, are predominant. And of mankind as a whole, this is even more true than of those individual men who have a fancy for ethics. We must look forward then for ourselves to a life-long-for the universe to 
a seemingly eternal-process of unrest, broken by transient moments of union with the whole of conscious life, by moments, that is, of devotion, of cheerful absorption in noble work, of strength in the admiration of other strength; by moments of sympathy and of self-sacrifice. Whether in sum there shall be more pains than pleasures in this series of conscious states, who knows? And who need care? Are we registering machines or men? We are viewing life solely with reference to the highest goal. What matters the rest of it?

This being our result, is it optimistic or pessimistic? Surely not what most people mean by the former. A life of endless battle, with temporary triumphs here and there, is no complete triumph. But is it complete failure? The goal never is finally attained, but is repeatedly attained, though but temporarily. The result is not the despair of disappointed romanticism, for we passed beyond that when we found that without activity no real triumph is possible. Nor is it that confused representation of an indefinite something with which the epilogue in heaven in Faust torments us. This sense of oneness with universal consciousness is a very simple experience: you can know it easily if you will but do a sacrificing act with purely unselfish motives, or if you will but give yourself up to the enthusiasm of a great popular cause, or if you will sit down and comfort a fellow-being in distress. Much nonsense can be talked about the matter; but, after all, the soul of true living is such experience. This life is my life: it is a rich moment when we say that of some other being, and were it but of a chirping, nestbrooding bird in the woods at twilight. Nor is our result a mere acceptance of activity as in itself enough. No, the activity is unrest; but through the unrest comes occasional rest. As for Schopenhauer's objection that the unrest predominates, we admit the fact. Schopenhauer's inference is that the will to live ought to be quenched. We reply that this is a matter not thus to be decided. As we first chose our goal by independent volition, so now we may choose how much hindrance of our endless efforts to reach the goal will be regarded as compensated by our occasional successes. Not the comparison of the two sums is desired, but the verdict of volition upon the worth of two sets of experiences. Which will you choose? That last question is simply unanswerable, except by a direct act of will. Here are the facts: A goal, viz., self-forgetfulness in the contemplation and creation of the fullest and clearest universal conscious life; a 
struggle to reach this goal, a struggle with blind nature, with selfishness within, with hatred without; this struggle alternating with periods of triumph; the process of alternating struggle and occasional triumph an endless process. How like you this life? It is the best that you are apt to find. Do you accept it? Every man has to deal with these queries quite by himself, even as with his own eyes he must see colors. It is our province merely to suggest the ultimate questions.

It has been the aim of the foregoing essay to present the question of pessimism in various historical lights, and to suggest a method of dealing with the problems involved. That these problems are deeply rooted in human nature seems plain. Unfortunate is the public apathy and light-headedness which declines to consider serious moral questions until accident forces them upon our notice. Pessimism is often regarded with horror; yet an earnest pessimist would be better than a sluggard of any creed. 